\title{
THE HORNBOOK METHOD AND THE CONFLICT OF LAWS
}

\author{
HESSEL E. YNTEMA
}

There is something of the heroic in the publication of a hornbook on the conflict of laws-if not of the suggestive. A squat, oaken paddle with the digits, the alphabet, and the Lord's Prayer inscribed thereon, the whole protected by a more or less opaque envelope of horn,-such was the hornbook primer of olden days. Our modern hornbooks are of much more liberal compass, yet, even so, will it be possible that the principles of the conflict of laws, which has often been invidiously described as the most difficult of legal subjects, can be profitably condensed into so narrow a format? Indeed, are there demonstrable principles of the subject which are worth insertion into a primer of legal lore? And, granting the demonstrability of such principles, might it not be more informing for the beginner to learn rather the methods of treating cases involving the foreign element than to memorialize trite formulae distilled from ancient precedent? An attempt to resolve these questions in a recent publication by Professor Goodrich, ${ }^{1}$ and to state in black-lettered principles the rules of the conflict of laws merits our earnest consideration.

Once an election is made to treat the conflict of laws in hornbook style,-in formulae fortified by commentary, - the tendency will be rather to reiterate contemporary tradition than to project a provoking critique into the future. The hornbook frowns on argument. Therefore, the difficult general questions of policy or method are likely to be left in the background or at best largely and apodictically expounded; too critical an approach would tend to deprive the established principles of law of the appearance of reality. Hence, in keeping with the hornbook character, the treatment can scarcely hope to develop from the point of view of sociological jurisprudence, of comparative law, or indeed of any science which will jeopardize its formal certitude. Whether the conflict of laws is a useful category for pedagogical or textbook purposes or rather one of the traditional miscellanies which grace our curricula (a point the implications of which I am not aware have been canvassed by the American Law Institute) ${ }^{\text {1a }}$; whether the problems so grouped should be formally treated so as to secure whatever definiteness logic may

1 HANDBOOI ON THE CONFLICT of LawS. By Herbert F. Goodrich, Professor of Law, University of Michigan. St. Paul, Minn., West Publishing Co., 1927. pp. xii, 500 .

2a The treatment of the Conflict of Laws by the American Law Institute involves numerous important questions, discussion of which cannot be attempted here. 
achieve or should rather be considered with a view to those more practical considerations of fact and policy which pragmatic philosophies are inevitably urging into the foreground of our legal thinking; whether an expanding commercial nation can afford to consider these problems exclusively from the insular point of view of the "common law"; how these rules of the conflict of laws are to be fitted into the various machineries by which uniformity is being achieved on some points and diversity maintained on others; whether the rules should be technically stated by reference to an hypothetical forum, a system of international principles, or a territorial "common law," -on these questions and their ilk which must vex the student who wants to think his way through the field, the hornbook, if it speak at all, must be oracular. In all this let us not be misunderstood. We are endeavoring to state the confines of the author's task, not to quarrel with his choice. For has not the American Law Institute in effect consecrated the hornbook method of stating principles as if they contained the essence of law, in what Professor Powell has been pleased to term its "primers" of law?

Hornbooks have, however, their uses as well as their limitations. And from this vantage-point Professor Goodrich's work must be judged. It is the first effort since the publication of Minor's work in 1901 at a comprehensive statement of prevailing doctrines as to the conflict of laws; as such it is bound to become significant. Even though it professedly cannot treat the various topics in detail, it will be found more informing than the cryptic publications of the American Law Institute which have thus far appeared in the field,-if only because the commentary is more complete and continuous. As such, the work will commend itself to the practitioner and in particular to the law student who prefers to dilute his reading of the cases with homeopathic doses of legal principle.

The work is divided into fifteen chapters which, with two chief exceptions, follow the order adopted in Lorenzen's case-book, which it parallels and to the cases in which references are given. The first exception is the treatment of marriage and divorce prior to that of property; the second is the introduction after the second chapter on domicil of a relatively long chapter on taxation. Furthermore, certain topics, such as agency, partnerships, foreign corporations, the relations between husband and wife and parent and child, bills and notes, carriers, bankruptcy and admiralty, which are more or less adequately treated in the case-book, are in the hornbook omitted because of want of space. Upon this classification of materials three remarks only need be ventured. The first is that the effect of introducing a chapter on domicil at the outset results in giving to that rather dubious concept an importance which seems disproportionate. The 
second is that the extensive segregation of the materials on foreign judgments from those on jurisdiction is apparently artificial and unsatisfactory, since so often the question as to the validity of a foreign judgment turns upon notions as to jurisdiction. The third is that this whole scheme of classification inadequately recognizes a bifurcation which is present throughout the subject-matter, i.e., between the problem of the proper court and the problem of the proper decision, or, in short, between jurisdiction and choice of law. The traditional classifications, which, for reasons of convenience, treat both sets of problems simultaneously, tend to obscure the fact that there is no necessary or fundamental connection between them. It remains to be added that the treatment of the various topics is somewhat uneven; domicil, taxation and the administration of estates are given relatively full treatment, while other topics such as contracts and property are much more summarily dealt with.

Turning now to questions of detail and reserving for the present the author's more general theories as to the purpose and nature of the subject, the statement may be ventured that no more has Professor Goodrich than the reporters of the American Law Institute satisfactorily shown either that our theories as to domicil, which they apparently regard as fundamental, are essentially different in their results from what would be the case were the appropriate cases settled by reference to residence and citizenship or, if so, that the theory by which a limited number of legal problems are determined by reference to the law of the domicil is preferable. The argument given on page 22 appears to assume that state citizenship cannot be used as a criterion, and suggests the large number of alien residents in this country as the basis of these theories. Having in mind the types of situations in which a technical domicil as distinguished from residence is used as a basis of decision, one may plausibly raise question on both points. Further items in the treatment of domicil may be noted. The stock definition, given on page 20 , which is there attributed to Story, we may recall, comes from the Code of Justinian. ' On the same page, we are told that the primary meaning of domicil is home, whilst on page 33 the expression "the legal relation called domicile" is used. In note 32 on page 30 , the author appears to discountenance "speculation in the realm of supposed intent" when dealing with questions of domicil; on page 32 , it is stated that, "To acquire a domicile of choice in a place, the person seeking to acquire it must actually be in that place at the time the intent to make it his home is present in his mind," a proposition which, taken literally, must be regarded as somewhat dubious. On page 29 , the revival doctrine is condemned as contrary to "fundamental principles of the law of domicil," an assertion which will perhaps seem a petitio prin- 
cipii to those who have read the English cases and those American cases which have followed Story,-see the references in the notes on page 30 . On page 24 , the author discards the renvoi doctrine as incompatible with common law principles. Artificial though the doctrine may be, it seems somewhat unsafe to reject it on a priori grounds. Conceivably, there may be situations in which its adoption may be necessary to do justice. In conjunction with the "intent and motive" principle on page 36, it would have been well to refer to the cases in which an indeterminate residence is taken up in a foreign jurisdiction for reasons of health. The statement on page 59 scarcely states the sound policy involved in the rule that the appointive guardian cannot move the ward's domicil to another state, and the statement on page 60 as to the powrer of the guardian of a lunatic to change the latter's domicil should be analogously qualified. At this point, it may also be noted that in the chapter on marriage, the validity of marriage is said to be ultimately determined by the len domicilii, a view which is in conflict with usual American theories. What the reviewer feels is the chief justification for our system of so-called rules as to domicil, namely that by reserving the wide door of intention they are really very flexible, does not seem to be suggested by the author. This merit can, however, scarcely atone for the fact that in generating the concept of domicil the most diverse legal situations have been indiscriminately huddled into a single catch-bag.

Similar difficulties are raised by the author's treatment of the jurisdiction of courts, though here again his analysis is quite traditional. As the author states, the term "deals with the power of a state, through its courts, to create rights which, under principles of the Conflicts of Laws, are entitled to recognition in other states." Apart from the implications of this metaphorical language, which will be considered below, it appears that the point of view adopted either takes as its standard a conceptualistic supra-state set of principles of jurisdiction or otherwise must fall back on the practices of individual states in dealing with foreign judgments. If the latter be the case, is it not to be expected that the foreign judgment will, in some measure at least, be estimated according to local procedural habits? Furthermore, what sound basis for isolating from each other the problems of municipal jurisdiction, of jurisdictional "due process" and of the so called international jurisdiction, (cf. pp. 118 and 139) or, indeed, for setting them in categories apart from the doctrines as to discretion in exercising jurisdiction, can be suggested; are not all these intimately related in their purposes, concepts, and nature? Again, the author accepts the usual classification of judicial proceedings as in rem, in personam, and quasi in rem. Serious question may be made as to whether 
attachment proceedings should not be regarded as peculiar in personam actions, if only to point to the inadequacy of our socalled fundamental rule of personal service in such actions. Certainly, it seems scarcely accurate to say, as does the author on page 138, that the fact of ownership confers no jurisdiction whatsoever to render a personal judgment or, if it be accurate, it seems inconsistent with the definition of Mr. Justice Holmes adopted by the author on pages 120 and 132 . The paragraphs on pages 137 and 138 as to personal jurisdiction based on domicil, however true they may be where the domicil and the residence are in the same place, suggest a query as to the propriety of basing jurisdiction upon a mere technical domicil. As to the state of the authorities on this point, there are questions which cannot here be stated, but at least the suggestion may be made that the distinction drawn by the author between McDonald $v$. Mabee and other cases seems too technical to be thoroughly satisfactory. The section on pages 151 to 156 , dealing with personal jurisdiction affecting matters outside the state,--though the reviewer approves of its inclusion,-scarcely seems congruous with the author's conception of the scope of the conflict of laws rules relating to jurisdiction. The standard involved is that of the forum and not of the foreign law, as the author seems to require on page 117. In concluding these brief remarks as to the author's treatment of the jurisdiction of courts, it is to be noted that on pages 146 and following the author accepts the customary analysis of the basis of jurisdiction over corporations, -an analysis which has never failed to amuse the reviewer by the naivete of its unreality. Any theory which premises as its concept of a corporation the artificial creature of legislative fiat is, bound to abound in anomalies as grotesque as those which Alice found in Wonderland. From the reviewer's point of view, if the premise is to be maintained, provided the particular rules as to service are known, it is as little important to decide whether the proper fiction shall be "consent," "presence," or "doing business," as it is to decide between the respective merits of tweedledum and tweedledee. As a starting-point for constructive thinking in this subject, as elsewhere, how much more useful a relatively realistic approach would be?

Incidentally, two points in the field of jurisdiction on which the author does not seem to have followed in extremis the pronouncements of the American Law Institute should be remarked. On page 123 , by not discussing Edgerly $v$. Bush, the author has successfully avoided the problems raised by the notorious section 52 of the Restatement on Jurisdiction. And on pages 139 and 140 the author, though seemingly somewhat inclined toward it, has yet refrained from adopting the remarkable reconcilia- 
tion of Grubel v. Nassauer and Douglas v. Forrest adopted in the same Restatement in sections 49 and 85 .

Thus far the reviewer has attempted to state briefly a few of the more immediate points suggested by a reading of the two chapters on domicil and on jurisdiction. As there is neither time nor space to tax the reader's patience much further, the remaining thirteen chapters must be dismissed with the inconclusive comment that more or less extensive queries of a similar character may be made as to each of them. However, even from this sampling, the discriminating reader will already have inferred that, aside from a certain laxity in expression which is the usual and almost inevitable consequence of a tendency to acquiesce in traditional blurred analysis, the author's general theories as to the nature and definition of his subject are responsible for the reviewer's chief difficulties. As this is not only a matter upon which opinions differ but is also of considerable importance at the present juncture, the reviewer feels that it is time to state the issue. For one thing, the activities of the American Law Institute in this field constitute an effort to perpetuate a doubtful technique: for another, the differences of opinion between the adherents of the so-called "territorial" theory of vested rights and those who are disturbed by its implications have been on at least two recent occasions stated in somewhat misleading terms. ${ }^{2}$ The reviewrer proposes therefore to state certain of the premises of the "vested rights" theory and the difficulties which that theory involves with such brevity as a complicated issue will admit. The matter is the more important, since it is paralleled by fundamentally similar problems in the other fields of law.

Of the premises accepted by Professor Goodrich, which are in effect also those of the great authority in this field, Professor Beale, it will be sufficient to recapitulate the following:

1. The conflict of laws deals primarily with the application of laws in space (p. 1).

2. The conflict of laws is part of the territorial "common law" (p. 8).

3. As such it is undesirable to study the subject by reference to civil law materials (p. 10).

4. The rules of the conflict of laws consist of "principles," according to which "rights once vested under the law continue until destroyed or cut off by law, ...... and are recognized and enforced in one state though they have come into being in another, unless such enforcement is,

2 See for example, Isaacs, Review of Lorenzen's Cases on the Confliet of Laws (1924) 38 Harv. L. Rev. 125; Beale, Rcview of Trestlalie's Trcatise on Private Intemational Law (1926) 39 HARV. L. REv. 530. 
for good reason, thought contrary to the public policy of the jurisdiction where enforcement is sought." (p. 10).

5. Uniformity in law comes through the study and understanding of these general principles (p. 10).

The question is whether these premises and the methodological system which they characterize afford the most useful points of departure, either for the accurate statement of existing legal practices or for its scientific development. The observations to be made follow two somewhat connected lines of inquiry.

The first and principal observation upon this method of dealing with the problems of the conflict of laws is that it is superficial and, to that extent, unscientific. (a) The account it takes of the social, economic and practical considerations of justice which have been urged in numerous fields more or less directly bearing upon technical law is quite inadequate. It suggests almost no correlation with the studies of a generation in sociological or functional jurisprudence and in inductive logic and scientific method, or with the studies of more than two generations in the various political and social sciences. In other words, it can be described only as a belated product of medieval scholasticism, or, if you prefer, of mid-Victorian transcendentalism, obsolescent before birth. To put the case more succinctly, it proceeds as if Dean Pound and those who believe with him that the problems of law are problems of social engineering and not of mechanical logic, had never "fit and bled" upon the battlefields of sociological jurisprudence.

(b) The premise that, since the principles of the conflict of laws are part of the common law of England, it is undesirable to study the solutions which have been reached in civil law systems is not only unscholarly but practically impolitic. As a matter of common sense, there can be scant justification for starting a supposedly scientific inquiry by the a priori exclusion of a field of materials which is germane and from which fruitful suggestions may be anticipated. Nor is the position defensible from a commercial point of view. A great commercial state, such as the United States has long since become, cannot afford, and least of all in the field of the conflict of laws, to remain in ignorance of the legal practices of the foreign countries with which there are a myriad contacts. The question whether our "common law" was, is, or shall be Anglo-Saxon is futile and beside the point. If it were at issue, the reply would suppose that we are neither British nor French, German nor Russian, but American, and, as such, entitled to the spiritual goods of all Europe.

Least of all can an adherent of the so-called "vested rights" theory in all self-consistency maintain this insular doctrine. In 
seeking common law principles to define the territorial scope of laws so as to decide when rights are vested, he is attempting for common law jurisdictions precisely what the European internationalist is attempting for the civil law. Is there any ground, aside from provincial prejudice and limited imagination, which can explain a refusal on the part of these two groups who have a common technique, a common set of problems, and a common objective, to join hands and extend the benefits of their system of artificial certainty over as wide an area as possible?

These remarks would be unnecessary were it not for the persistence with which the traditional view has maintained itself. Professor Beale has put the position as definitely as it could be stated:

"Apart, however, from questions of national jurisdiction there can be little doubt that the principles of the conflict of laws are in the fullest sense principles of the municipal law of each country. With us such questions are solved or should be solved entirely in accordance with common-law principles and analogies; and to follow the authority of writers on the modern civil law is as improper as it would be to accept from a continental writer the doctrine that a written contract requires no consideration. The practice introduced by Lord Mansfield, or at least in his time, of turning to civil law authors and authority, and continued by several scholarly American lawyers during the first third of the nineteenth century was not one which has tended to preserve the correctness and parity of the common law." ${ }^{3}$

Historically, this passage bristles with paradoxes. The existence of a "correct" and coherent system of rules as to conflicts of laws in the English common law during the eighteenth century or before would be difficult to demonstrate from the books. In great part, our present doctrines in this field are a relatively recent nineteenth century development, which was chiefly influenced by the decisions and works of great jurists, such as Lord Stowell, Kent, Story, Westlake, and Dicey, the most important of whom were familiar with the continental theories of their time and drew upon them for suggestions. So, if the matter were to be argued only on the sterile basis of tradition, there would seem to be good enough precedent for some consideration of civil law materials. Only this well-known civilian background of many of our doctrines as to the conflict of laws will explain Professor Goodrich's statement on pages 168 and 169, that although prior to the middle of the eighteenth century the common law had been developing for years almost free from foreign influence, the construction of the statutes of limitations as remedial was influenced by the writings of the Dutch jurists.

${ }^{3}$ Beale, What Law Govems the Validity of a Contract (1909) 23 Hisv. I. REv. 1, 8. 
Incidentally, when one begins to speculate about the possible provenance of the vested rights theories, bizarre analogies emerge. For instance, the very definition of the subject, conflict of laws, as "that which deals primarily with the application of laws in space," with which Professor Goodrich commences his handbook and which he has avowedly accepted from the writings of Professor Beale, appears to go back, as will appear even from the latter's Treatise on the Conflict of Laws, pages 1 and 2, to Bustamente and ultimately to Savigny, both of them civilians. And, to give another illustration, the paragraphs on pages 153 and 154 of the same treatise on the generality and continuity of legal principles are strangely reminiscent of the excerpt from Pillet's work, which is to be found in translation in 2 Beale, Cases on the Conflict of Laws, at page 3. Can it be that in this discussion we are struggling with a theory which was conceived in the midst of civilian pandects and not a pragmatic product of the common law?

Notice that we neither suggest nor deprecate the introduction of civil law theories as such. What is proposed is that our study of these theories and of common law practices in this field be supplemented by a somewhat serious study of the administration of justice in foreign countries in relation to its social background, both that we may be, if only for commercial reasons, informed thereof, and that the consideration of our own legal problems may be more objective.

The further observations to be made upon the so-called territorial theory of vested rights as a basis either for stating the law or for insuring its scientific development are to the effect that the theory imports a terminology inept to describe the factors involved in legal problems and a technique inadequate either to state accurately the practices of courts or to control their decisions. Numerous considerations are at the basis of this statement, only a few of which can be sketched in this connection. (a) One of the primary difficulties with the vested rights theory is the figurative and undifferentiated character of its terminology. To say that laws "exist" within defined geogxaphical limits; that by these laws rights are "created" and so "exist" until they are destroyed by operation of law; that, furthermore, there are "principles" which invest these rights with the powers of migrating from state to state; and that by virtue of these principles rights so vested are recognized and enforced in foreign courts-is to express in crass symbols the most complex syntheses of phenomena. Even so, the metaphorical expression that principles or rights exist is oftentimes a useful mode of speech and not in itself objectionable, so long as we are aware that we have merely given a label to a complicated experience, real or supposed. We must needs talk and probably also think 
in symbols of sign and sound. The difficulty is rather that the symbols of the vested rights theory neither correspond to the social and economic factors with which courts deal nor even accurately suggest the things which are done in courts. Hence flows the chief vice of this and similar too abstract conceptualistic theories of law, that, because the symbols used are too ferr and too remote from reality to represent it, they force those whose thoughts are limited to these symbols finally to iegard them as reality and to believe that by employing them in the processes of formal logic, "correct" results may be obtained. A simple illustration will suggest the point. The hypothesis, two plus two equals four, is true as an abstract proposition if we accept certain premises; but it is by no means a universally useful method of stating experience, as the addition of two parts of hydrogen to two of oxygen will demonstrate. If the realm of law were like mathematics, compounded of hypotheses or of the stuff which dreams are made of, no one could object to peopling the legal world with principles, rights or other juristic constructions. But law is not logic, however usefully logic may be made to serve the ends of law. And any system of thought so fragmentary as to base the actual statement or reform of law upon purely logical deductions from combinations of abstract symbols without careful analysis of the practical purposes of legal traditions and institutions considered with reference to the concrete case is not merely obscurant but socially dangerous. Only by constantly checking the hypotheses resulting from logical manipulations against observation and experience can we hope to approximate practical truth or justice in the administration of law.

(b) As it is stated, the vested rights theory is either an elliptical tautology which leads us nowhere or otherwise it is disingenuous. In either case, it can scarcely be considered either an appropriate vehicle for describing legal practice or an effective means for directing the decision of a court. If we are told that rights which become vested under the proper law are usually enforced in foreign jurisdictions, the natural inquiry arises as to the process by which this investment occurs. Apparently, we are to believe that the investment takes place under the influence of certain common law principles to the extent that these principles are uniformly adopted in the various jurisdictions as to which there is inquiry. The obvious inference is that rights are vested when and because they are vested, which completes this circle. An illustration of the difficulties inherent in this mode of analysis will be found in Professor Goodrich's apparent query as to the important but misnamed distinction between substance and procedure. As he says: "The distinction is made by courts, and the lawyer must figure it out as best he can." 
(note on page 159). Obviously, from the viewpoint of a consistent vested rights theory the distinction cannot be justified, and the difficulty is only stated by elaborating an intricate system of rights, primary, secondary, and remedial, such as is adopted on page 158. Surely, on this theory, a right which is once panoplied by the powers, privileges, and immunities of a given system of law ought to take with it that full panoply wherever it goes, if it is not to become a disfigured ghost. And yet everyone knows that no such scheme will be ever adopted this 'side of the millenium. If we approach the question from a practical lawyer's point of view or that of the judicial administrator, the difficulties vanish in the proportion that we depart from occult manners of speech and consider the realities. No foreign right ever entered a foreign court or, indeed, any court, nor has any court, strictly speaking, ever seen or physically enforced a right. All this is a colorful and somewhat befuddling metaphor. An attorney appears and puts in a claim. As part of his proof required by the legal practice of the forum, he puts in evidence an authenticated copy of a statute, a judicial decision, or a judicial record, emanating from another jurisdiction. It becomes a part of the evidence in the case. And, in the last analysis, it is a simple question of convenience and equity, roughly controlled by the traditions of the forum, as to how far the court will, can, or should relax its domestic habits of decision to give a judgment more or less remotely resembling that which might be secured in the court of another jurisdiction. The basis of departure is the practice of the forum and the equities of the instant case, and not universal principle or vested right. In the field of the conflict of laws, as in other branches of law, the problem is essentially one of the adjustment of actual interests and not of formal logic.

If, however, we interpret the theory of vested rights to mean that "rights once vested under the proper law" should be enforced in the foreign court, our theory is disingenuous, or perhaps ingenuous, since we are assuming the very point at issue, i.e., whether particular claims should be so enforced. It is doubtless true that in many situations the result is the one to be desired, but it is not satisfying from a practical or even a logical point of view to start out by assuming the conclusion. A mode of analysis is required which will state and estimate the equities and conveniences and so reach its conclusions. To do so efficiently, we shall need not only a more precise and flexible terminology but also both careful study of individual cases from the point of view of social and judicial engineering and information as to the fact-situations and the foreign legal practices with which we are dealing.

The point of view which we are stating will inevitably meet 
the criticism that, in attempting to secure justice in the individual case, we have discarded the possibility of uniformity and certainty in the administration of cases involving the foreign element. The argument is, in sum, that the so-called "uniform enforcement of vested rights" can only be approximated by assuming the general principle that there is to be uniformity. There are various difficulties with this argument of policy as to how doctrines of the conflict of laws should be formulated. As a preliminary point, we may remind ourselves that it can by no means be assumed that uniformity and certainty are the sole ends to be attained. There may be, and we cannot ascertain until inquiry, situations in which the foreign law may be so obsolete or so inimical to the social interests of the forum that to apply the doctrine would defy justice. Here, as elsewhere in the law, summum ius summa iniurio. In fact it may be discovered that a discretionary porrer of rejecting the foreign law in such cases may in the long run conduce to the sound and uniform development of legal doctrine in this country. Such doctrines as that of a "federal common law" have an importance which we have not as yet attempted to ascertain. Again, a general principle of uniformity, as we have attempted to suggest above, can never correspond to the realities of judicial administration. This is so, far more largely than we dare admit, even within a single system of courts. The probabilities of variation are multiplied when the courts of one system attempt to follow the practices of another, as to which they must remain relatively ignorant so long as we are to rely merely upon vague general principles to inform them. And, in any case, there will always be a large area of questions in which, because of the necessities of an economical administration of justice, courts will necessarily follow their local practice. In this situation, it will probably be safer, if we must suggest a general principle, to insist upon a just decision than upon one which may as well as not be erroneously believed to be uniform.

The argument that uniformity can be secured only by disingenuity in the statement of general principles, is one by which we are not to be moved for an even more potent reason,-it is simply not so. The ideal of a government of laws and not of men is a dream which will have to wait for the time when law becomes calculus to be realized. Still less can it be said that the administration of justice is controlled by general principles. The history of codes and of legislation, or even of language, should have taught us long since that rules and principles are empty symbols which take on significance only to the extent that they are informed with the social and professional traditions of a particular time and place. Those who disbelieve may regard the manner in which the greatest of our codes has been inter- 
preted, the Constitution of the United States. It is not the symbols but the habits of thought that control interpretation and decision. In dealing with situations involving a foreign element, the habits of thought which we encounter in judges and lawyers are not normally concentrated primarily upon the foreign element. Whether the problem be one of the recognition of a foreign judgment or of the effect to be given a complicated letter of credit transaction, the pattern is furnished by the traditions of the forum and the experience of the concrete factsituation. This is properly so, if an efficient result is to be attained, since the foreign element, the circumstance that events transpired in another jurisdiction, is only one, and often an incidental, aspect of the case. Furthermore, of the many things which have been said as to the mystery of the judicial process, the most salient is that decision is reached after an emotive experience in which principles and logic play a secondary part. The function of juristic logic and the principles which it employs seems to be like that of language, to describe the event which has already transpired. These considerations must reveal to us the impotence of general principles to control decision. Vague because of their generality, they mean nothing save what they suggest in the organized experience of the one who thinks them, and, because of their vagueness, they only remotely compel the organization of that experience. The important problem in the conflict of laws is not the formulation of the rule but the ascertainment of the cases to which, and the extent to which, it applies. And this, even if we are seeking solely uniformity in the administration of justice, will lead us again to the circumstances of the concrete case, and to the careful study of foreign practices. The reason why the general principle cannot control is because it does not inform.

We have in the foregoing discussion directed our attention chiefly to the general premises of the "vested rights" theory, since they necessarily and conveniently suggest the limitations of the method by which conclusions are to be reached under more specific rules. "But," our hornbook interlocutor will persist, intransigeant in his conceptualism, "even if the general principles are, as you suggest, lights that shed no illumination upon legal problems, yet at least you will grant that the law must be stated in specific rules, and of such are hornbooks made. Surely, these rules of law are the law; we cannot conceive of law in other terms than rules and principles." Yes, the law must be stated in concepts and rules, but the inference which our interlocutor proposes to draw simply drives the ancient error back another stage and reveals on his part either lack of apprehension or misapprehension of the point of view which we have essayed to sketch above. The crux of the matter is really that 
law is a practical thing; it has to do with human activities, the doings of judges and lawyers, of legislators and, above all, of socially organized individuals. Which is to say that law is not a theoretic but an applied science. Of course, we must have a legal language. Human activities must be analyzed and described for legal purposes in terms and rules, all of them symbolic of the activities to which they advert. But to say that the rule is the law, that the symbol is reality, leaves us still in the squirrel-cage of conceptualism; it is only less objectionable than defining law in terms of general principles to the extent that the rules embrace a narrower scope. It should be obvious that when we have observed a recurrent phenomenon in the decision of cases by the courts, we may appropriately express the classification thus adopted in a rule. But the rule will be only a mnemonic device, a useful but hollow diagram of what has been. It will be intelligible only if we relive again the experience of the classifier and will be safely employed only with knowledge of its limited purpose and of the scientific deficiencies of the decisions from which it is abstracted. Thus understood, the language of the law, its concepts and rules, is indispensable as a vehicle for expressing thought. This it can do but imperfectly and more it cannot. The rule can state in convenient abstract form the common element in a number of historical judicial events, but it cannot tell us whether any judicial decision or, indeed, the decision in some future case should come within the rule. To decide questions of this nature, we must ultimately probe the purposes and the prejudices implicit in the judge's reaction to the concrete case; we must strive to verify the validity of that reaction by reference to scientifically organized data; we must above all desire an objective estimate of the probable practical consequences thereof. The table of logarithms and the formulae of stresses and strains are invaluable to the engineer, but they cannot tell him whether the bridge is to be built or, if so, where, nor how high and how broad it is to be and how much it will cost. To say that the rule of law is law, that by reference to abstract rules we may control decision and determine whether cases have been "correctly" decided, is in effect to assert the social practicability of the decision, if found "correct," without attempting to ascertain whether it is useful. And this is the ultimate fallacy in the realm of applied science.

It remains to be remarked that one of the most important implications of the vested rights theory is in the field of constitutional law. The doctrine has already been intimated in dicta of the Supreme Court and it has even been stated with unblushing generality in the law reviews "that a right vested under the

* Dodd, The Power of the Supreme Court to Revicw State Decisions in the Field of Conflict of Laws (1926) 39 HaRv. L. REv. 533. 
principles of the conflict of laws is entitled to constitutional protection under one or another of the various blanket clauses which are available, the due process clause, the impairment of contracts clause, the interstate commerce clause, or the full faith and credit clause. Thus far it seems that the Supreme Court, in addition to the foreign judgment cases, has employed this vested rights analysis in two types of cases involving conflicts of laws. The first type is that furnished by cases involving insurance contracts, ${ }^{5}$ in which the court is obviously threatening to flank Paul v. Virginia, and the second type is composed of cases involving corporations or associations in which a wide definition is given to "parties in interest" regarded as concluded by judgments in stockholders' and analogous actions. ${ }^{\circ}$ In these situations, strong economic and governmental motives are in operation behind the formulae, so that from the practical point of view it would at the present time be unsafe and unsound to generalize the dicta in these decisions into a theory of unlimited federal competence in the field of the conflict of laws. The point worth noting, however, is that under vested rights doctrines there is no logical stopping-place short of this result. If uniformity in dealing with conflict of laws is the sole desideratum and the efficient means of securing it is federal action, there can be only one sensible and inevitable solution. Whether such a solution would be desirable or not is not at issue in the present discussion. The point is that the vested rights theory suggests the solution of federal control without enabling us to know whether it is desirable. That is not a question of formal logic or of general principles, but of expediency, which turns upon the ascertainment of the facts of particular cases and the social and governmental policies which are to control. Because a certain degree of centralized judicial administration ultimately controlled by the Supreme Court is feasible and probably desirable in the case of the nationally organized insurance business, it by no means follows that federal intervention is indicated in the case of horse-trades, of building and loan contracts, of promises to marry, of testamentary dispositions or in a myriad other transactions. The similarity of transactions which the vested rights theory necessarily supposes leaves us in Stygian darkness as to almost all the concrete problems involved in each case. The only safe or reasonable procedure, the only procedure which conforms to common law traditions, is to test each case on its merits. Any realistic or useful analysis must be planned on this basis. The vice of the vested rights theory is that it affects to

${ }^{5}$ Aetna Life Insurance Company v. Dunken, 266 U. S. 389, 45 Sup. Ct. 129 (1924).

${ }^{6}$ Royal Arcanum v. Green, 237 U. S. 531, 35 Sup. Ct. 724 (1915). 
decide concrete cases upon generalities which do not state the practical considerations involved and so it must perforce obscure the issue.

Unfortunate as it may appear to pin the onus of a traditional point of view upon a single volume, it has in the present case seemed necessary to do so, both because Professor Goodrich's work is representative of the vested rights tradition and because of its importance as the first comprehensive statement thereof which we have had for a generation. That the publications of the American Law Institute on the conflict of laws start from the same theoretical premises and employ the same formal methods of statement and solution makes it the more desirable to state the issue as to the usefulness and limitations of the hornbook method in the field of the conflict of laws. This by no means implies, as indeed has already been suggested, that Professor Goodrich's work will not be found useful, particularly by students. As a treatise on the conflict of laws, it is an excellent hornbook. But it does imply the belief that the era which was satisfied with solving its legal problems by fundamental principles of juristic theology is fast passing and the hope that future studies in the field of the conflict of laws may give more specialized attention to the realities of judicial administration. 